\title{
Effect of Fluoride Sodium Mouthwash Solutions on cpTi: Evaluation of Physicochemical Properties
}

\author{
Marcelo Bighetti TONIOLLO \\ Rodrigo GALO \\ Ana Paula MACEDO \\ Renata Cristina Silveira RODRIGUES \\ Ricardo Faria RIBEIRO \\ Maria da Gloria Chiarello de MATTOS
}

Department of Dental Materials and Prosthodontics, Ribeirão Preto Dental School, USP - University of São Paulo, Ribeirão Preto, SP, Brazil

\begin{abstract}
The effects of fluoride, which is present in different oral hygiene products, deserve more investigation because little is known about their impact on the surface of titanium, which is largely used in Implantology. This study evaluated the surface of commercially pure titanium (cpTi) after exposure to different concentrations of sodium fluoride (NaF). The hypothesis tested in this study was that different concentrations of $\mathrm{NaF}$ applied at different time intervals can affect the titanium surface in different ways. The treatments resulted in the following groups: GA (control): immersion in distilled water; GB: immersion in $0.05 \% \mathrm{NaF}$ for 3 min daily; GC: immersion in $0.2 \% \mathrm{NaF}$ for $3 \mathrm{~min}$ daily; GD: immersion in $0.05 \% \mathrm{NaF}$ for 3 min every 2 weeks; and GE: immersion in $0.2 \% \mathrm{NaF}$ for 3 min every 2 weeks. The experiment lasted 60 days. Roughness was measured initially and every 15 days subsequently up to 60 days. After 60 days, corrosion analysis and anodic polarization were done. The samples were examined by scanning electron microscopy (SEM). The roughness data were analyzed by ANOVA and there was no significant difference among groups and among time intervals. The corrosion data $\left(i_{\text {corr }}\right)$ were analyzed by the Mann-Whitney test, and significant differences were found between GA and GC, GB and GC, GC and GD, GC and GE. SEM micrographs showed that the titanium surface exposed to NaF presented corrosion that varied with the different concentrations. This study suggests that the use of $0.05 \% \mathrm{NaF}$ solution on cpTi is safe, whereas the $0.2 \% \mathrm{NaF}$ solution should be carefully evaluated with regard to its daily use.
\end{abstract}

Key Words: fluorides, titanium, dental materials, surface properties.

\section{INTRODUCTION}

The increasing interest in the use of titanium in dentistry is due to the great clinical success of commercially pure titanium (cpTi) in osseointegrated implants. Titanium has also excellent properties, such as good corrosion resistance, biocompatibility, low density, low thermal conductibility and good resistance regarding weight (1). Studies found that $\mathrm{cpTi}$ can be cast and applied to a mold using special investment and casting techniques (2).

$\mathrm{CpTi}$ forms a thin oxide layer due to its high reactivity to certain elements, especially oxygen, and that property provides it with a high corrosion resistance and proper adherence of the porcelain to the metal (3). $\mathrm{CpTi}$ has a great biocompatibility to soft and hard tissues. On the other hand, different products used in the oral cavity contain many substances that can affect titanium. For example, fluoride is often used in mouthwashes, chewing gums and dentifrices, and it can affect cpTi properties (4).

In this context, the main application of titanium, which is exactly in Implantology, could present real problems. Although the implant binds directly to bone, and so it would be isolated from the fluids present in the oral cavity, there are several situations in which this binding might be impaired, exposing the implant to the oral environment, such as a possible exposure of the

Correspondence: Profa. Dra. Maria da Gloria Chiarello de Mattos, Departamento de Materiais Dentários e Prótese, Faculdade de Odontologia de Ribeirão Preto, USP, Avenida do Café, S/N, 14040-904 Ribeirão Preto, SP, Brasil. Tel: +55-16-3602-4098. Fax: +55-16-3633-0999. e-mail: gloria@ forp.usp.br 
implant cervical region originated from bone resorption, saucerization or limitations for its full positioning into the bone, which vary according to the case (5). Another situation of titanium exposure to fluorides would be with respect to the components involved in implant-supported denture rehabilitation with this material (5-7). Thus, fluoride could be harmful to rehabilitation treatment involving implants.

The corrosive effect of fluorides on the protective passive layer of titanium and the use of fluoride products in the oral cavity have been studied by several authors (2,8-11). Studies have also shown that the effects of prophylactic agents containing fluorides can be harmful to the mechanical properties of Ti alloys $(12,13)$. The literature also shows that a titanium surface exposed to any substance containing fluoride results in an altered surface topography (14-16).

The effects of fluoride, which is present in different oral hygiene products, deserve more investigation because little is known about their impact on the surface of cpTi casts. The hypothesis tested in this study was that different concentrations of sodium fluoride $(\mathrm{NaF})$ applied at different time intervals can affect diversely the cast titanium surfaces in prostheses.

\section{MATERIAL AND METHODS}

\section{Materials and Sample Preparation}

Fifty disc-shaped $(8 \mathrm{~mm}$ diameter and $2 \mathrm{~mm}$ thick) wax patterns were invested in Rematitan Plus (Dentaurum, Pforzhein, Germany), and casts were made by the lost-wax technique using cpTi (Tritan grade I; Dentaurum) in a casting machine (Discovery Plasma; EDG, São Carlos, SP, Brazil), which applies an electric arc melting under vacuum in an argon atmosphere, with injection of the metal into the mold by vacuum pressure, according to manufacturer's instructions. The cast specimens were carefully cleaned using $50 \mu \mathrm{m}$ aluminum oxide airborne particle abrasion for $15 \mathrm{~s}$ to remove investment debris. The specimens were ground wet up onto 2000-grit silicon carbide papers, and were ultrasonically cleaned in ethanol for $15 \mathrm{~min}$ and washed with distilled water.

Five groups $(\mathrm{n}=10)$ were formed according to the fluoride-containing solutions where the specimens were immersed during the experiment. The $\mathrm{NaF}$ solutions, $\mathrm{pH}=7$, were prepared at the School of Pharmaceutical Sciences of Ribeirão Preto, USP, Brazil.
The 5 groups were further subdivided into 2 groups: 1) specimens for roughness test $(\mathrm{n}=5)$ and 2) specimens for corrosion tests $(\mathrm{n}=5)$. Fluoride was applied on the metal for a short period of time $(3 \mathrm{~min})$ to simulate the common experience of a patient. The immersion times can be found in Table 1 (8). Surface roughness was measured at the following intervals: $\mathrm{T} 0$ (initial reading after sample polishing), T15 (after 15 days), T30 (after 30 days), T45 (after 45 days) and T60 (after 60 days). The specimens were kept immersed in distilled water throughout the experiment and were exposed to fluoride $(20 \mathrm{~mL})$ only under specific conditions, once a day or every 2 weeks. Surface roughness of the cpTi specimens was measured with a profilometer (SJ201-P; Mitutoyo, Tokyo, Japan) with $300 \mathrm{~mm}$ accuracy, $0.5 \mathrm{~mm} / \mathrm{s}$ speed and five $0.8 \mathrm{~mm}$ cut-offs.

Three readings were taken from each specimen (at the center of the specimen, $1 \mathrm{~mm}$ to the right and 1 $\mathrm{mm}$ to the left) and the mean was calculated for each specimen and for the group (8). All specimens remained immersed in distilled water throughout the experiment at $37^{\circ} \pm 1^{\circ} \mathrm{C}$ and were removed only for immersion in the fluoride-containing solutions, after which they were dried with absorbent paper.

The specimens selected for the corrosion test were not submitted to roughness readings. The corrosion test was performed at the end of 60 days of exposure.

\section{Electrochemical Measurements}

The electrochemical measurements were made using a potentiostat (PGP201 Radiometer Analytical,

Table 1. Different concentrations of fluoride solutions and application times for each test group.

\begin{tabular}{lcc}
\hline $\begin{array}{c}\text { Group } \\
(\mathrm{n}=10)\end{array}$ & $\begin{array}{c}\text { Solution with vibrated } \\
\text { immersion }\end{array}$ & Application time \\
\hline GA & Distilled water & $\begin{array}{c}\text { Throughout the } \\
\text { experiment }\end{array}$ \\
GB & $\begin{array}{c}0.05 \% \text { NaF aqueous } \\
\text { solution }\end{array}$ & Daily (for 3 min) \\
GC & $\begin{array}{c}0.2 \% \text { NaF aqueous } \\
\text { solution }\end{array}$ & Daily (for 3 min) \\
GD & $0.05 \%$ NaF aqueous & Every 2 weeks (for \\
solution & 3 min) \\
GE & $0.2 \%$ NaF aqueous & Every 2 weeks (for \\
& solution & 3 min) \\
\hline
\end{tabular}


Copenhagen, Denmark) controlled by the VoltaMaster-4 software run on a computer (VoltaMaster; Radiometer Analytical). The edge of the sample area was defined by pressing a sample against an o'ring and exposing an area of $3.64 \mathrm{~cm}^{2}$. Potentials were measured against a standard calomel electrode-SCE (B20B110; Radiometer Analytical) and a platinum plate served as the counter electrode, with an exposure area of $1 \mathrm{~cm}^{2}$ (wire B35M110; Radiometer Analytical) (17).

Before testing, the specimens were ultrasonically cleaned (Ultrasound 1440 D Medical; Dental Equipment Trade Ltda, Ribeirão Preto, SP, Brazil) in ethanol for $10 \mathrm{~min}$ and in distilled water for $10 \mathrm{~min}$. The samples were dried with hot air and kept in the desiccator until the beginning of the test.

The corrosion potential $\left(\mathrm{E}_{\text {corr }}\right)$ was measured 1 $\mathrm{h}$ after immersion. Afterwards, the potentiodynamic polarization curves were drawn from $-500 \mathrm{mV}$ to $+2,000$ $\mathrm{mV} v s \mathrm{SCE}$ with a scanning rate of $2 \mathrm{mV} / \mathrm{s}$; all the tests were carried out at $37 \pm 1{ }^{\circ} \mathrm{C}$. The test was repeated at least 5 times per condition (17).

\section{Surface Analysis by Scanning Electron Microscopy}

After the surface roughness and corrosion tests, the specimen surfaces were examined using a scanning electron microscope (JSM-5410; Jeol, Tokyo, Japan) to identify possible sites of corrosion attack. The samples were properly stored in closed containers until the tests were conducted.

\section{Statistical Analysis}

The roughness data were analyzed by ANOVA for the influence of $\mathrm{NaF}$ on cpTi. Tukey's test $(\mathrm{p} \leq 0.05)$ was chosen for multiple comparisons of difference

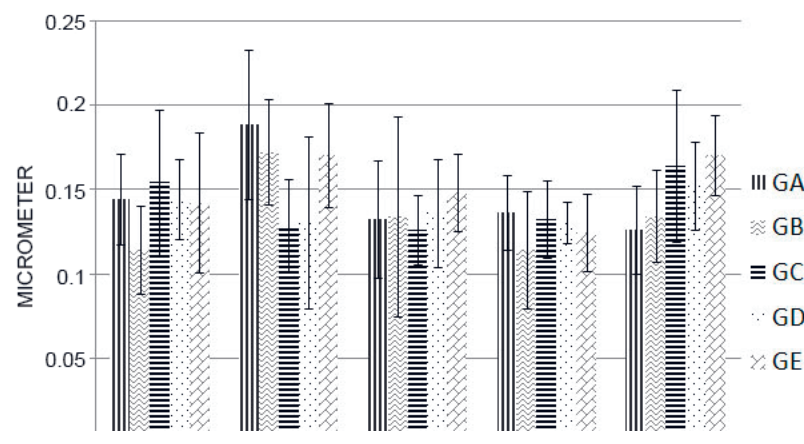

Figure 1. Mean values and standard deviations of surface roughness at different times. among groups and times. The corrosion density $\left(i_{\text {corr }}\right)$ was analyzed by the Mann-Whitney test. Statistical analysis was performed using SPSS software version 12.0 (IBM Company; Chicago, IL, USA).

\section{RESULTS}

No statistically significant differences $(p>0.05)$ among groups and among time intervals were found for roughness values (Fig. 1).

The evolution of the open circuit potential with time for the different $\mathrm{NaF}$ concentrations is shown in Figure 2. GA (-195.2 $\pm 47.98 \mathrm{mV} / \mathrm{SCE})$, GD $(-360.6 \pm$ $9.56 \mathrm{mV} / \mathrm{SCE})$ and Group E $(-349.6 \pm 22.2 \mathrm{mV} / \mathrm{SCE})$ increased their tendency towards corrosion after contact with distilled water. GA stabilized after $30 \mathrm{~min}$, whereas GD and GE continued to increase their tendency to corrosion. However, GC (-285.8 $\pm 64.75 \mathrm{mV} / \mathrm{SCE})$ and GB $(-316.6 \pm 79.65 \mathrm{mV} / \mathrm{SCE})$ presented a decrease of the tendency to corrosion.

The potentiodynamic data of the groups are presented in Figure 3. The current density is correlated with the corrosion rate. A high current density (current on the surface) at the corresponding potential indicated a high corrosion rate on cpTi.

After potentiodynamic polarization tests, the cpTi surfaces were examined by scanning electron microscopy (SEM) (Fig. 4) and demonstrated high corrosion according to the concentration.

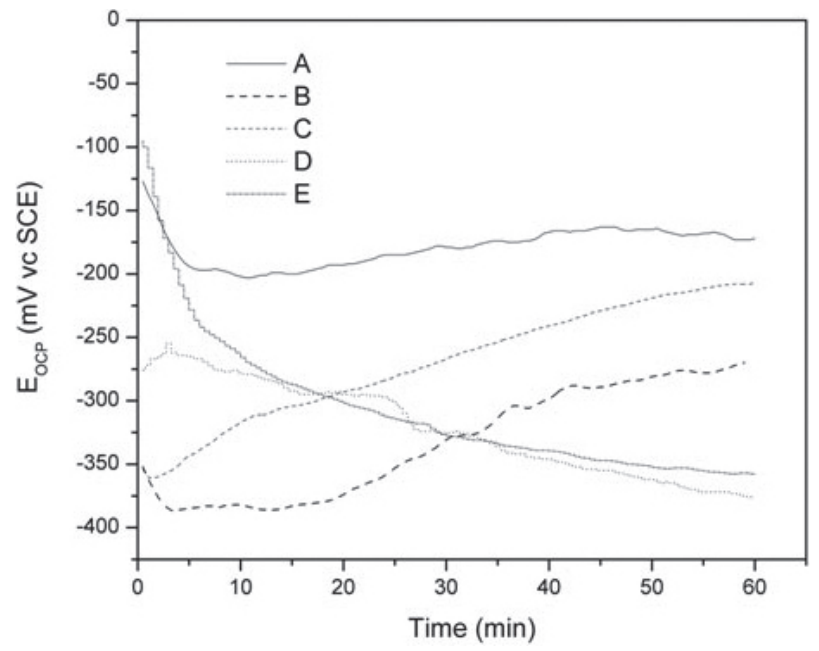

Figure 2. Potentials recorded under open-circuit conditions for the different $\mathrm{NaF}$ concentrations and application methods versus time. 


\section{DISCUSSION}

The oral environment promotes corrosion due to changes of temperature, $\mathrm{pH}$, humidity, oxygen and food decomposition. Fluoride is one of the elements that can modify the metal surface and it can be found in different concentrations in mouthwashes and toothpastes. The effects of fluoride on the corrosion behavior of titanium and its alloys have been presented by other authors $(12,15)$. According to their results, whenever in contact with the fluoride solutions, the oxide film undergoes a reaction resulting in the formation of titanium fluoride, titanium oxide fluoride or sodium titanium fluoride on the alloy surface and the corrosion resistance decreases markedly in these fluoride solutions.

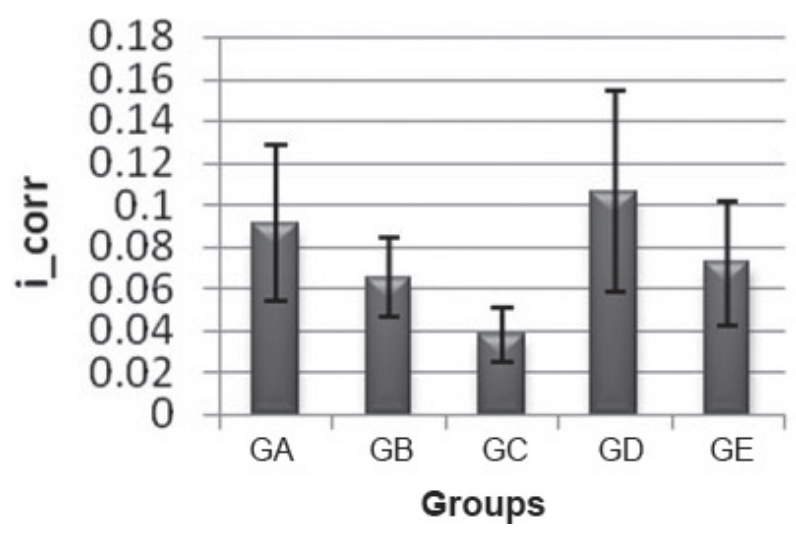

Figure 3. Mean values of $i_{\text {corr }}$ and standard deviations for the studied groups.
The results of the surface roughness measurements, in contrast to those presented by Mabilleau et al. (15), showed no significant difference of the action of fluoride on the cpTi surface. The exposure of the specimens to fluoride under specific conditions, namely once a day or every 2 weeks, possibly provides conditions for the renovation of the passivating layer, as proposed by Hruska and Borelli (18) and Elagli et al. (19), thus preventing more detectable adverse effects on cpTi surface. Furthermore, preservation of titanium surface, regarding to roughness, may have been due to the mere exposure of the metal surface to the ion fluoride without the association of any other mechanical interaction, such as brushing, which could have limited the release of ions (20). Additionally, this mechanical action would remove the layer of deposits formed on the surface of the titanium, eliminating their protective function of the layer. This action would lead to the continuous exposure of the metal and promoted its degradation.

Evaluations of the $i_{\text {corr }}$ mean values in the studied groups, within the different experimental conditions, suggest that GD had the highest corrosion rate, followed by GA, GE, GB and GC, as presented in Figure 3.

GC is noted in all data comparisons, which show the disparity between the daily immersions in $0.2 \% \mathrm{NaF}$ solution and the other conditions. However, the mean value for GC was statistically significant for less, not more, than expected. Apparently that group presented the lowest corrosion rate. However, the lowest mean value found for GC showed the largest accumulation
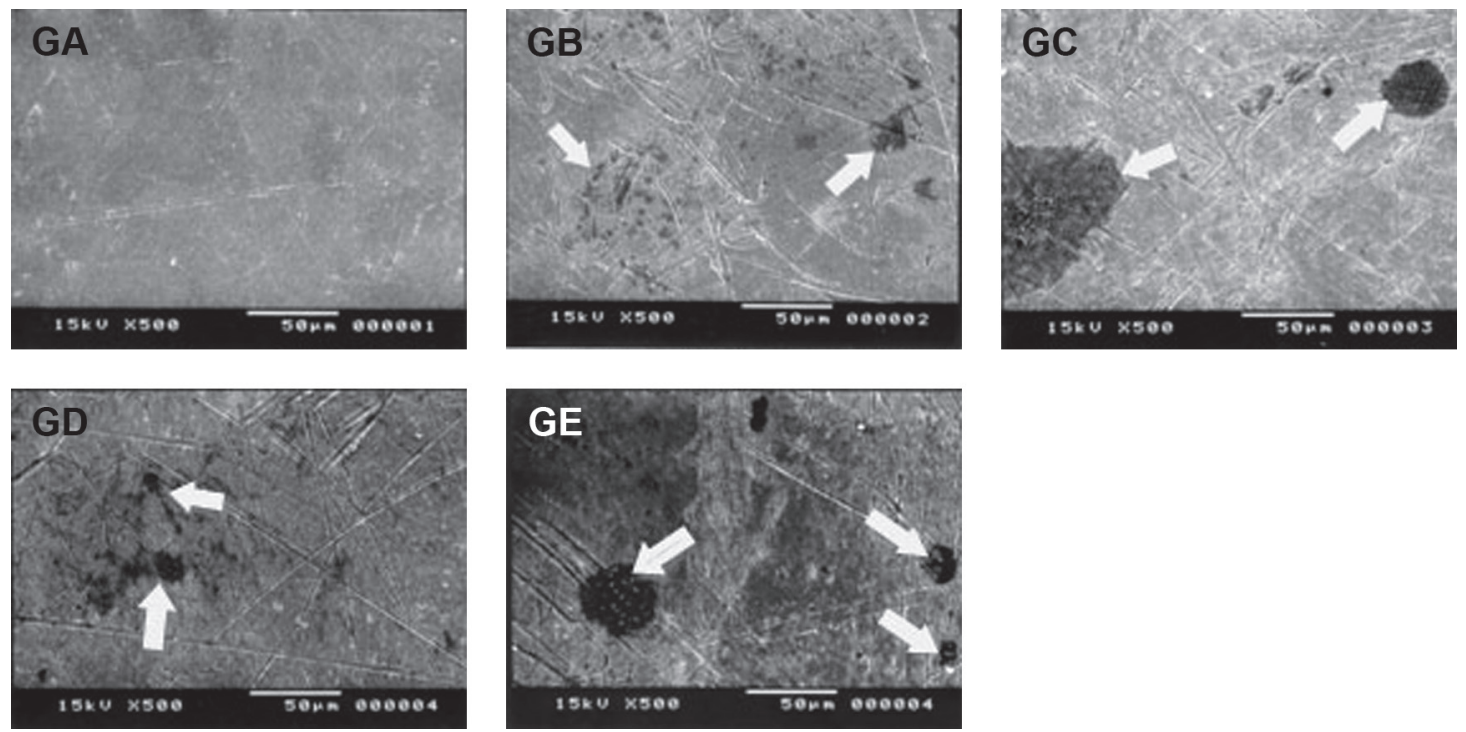

Figure 4. Composite figure of SEM images of the studied groups. The white arrows indicate corrosion debris. 
of deposits on the surface of cpTi induced by an initial intense corrosion, indicated by the arrow in Figure 4. These deposits provide a protective barrier and decrease the $i_{\text {corr }}$ value (21-23). The same results did not occur with Group E, mainly due to the fact that immersion in $\mathrm{NaF}$ solution was made only every 2 weeks. It is essential to note that no mechanical action that could remove the deposits formed was used on the metal surface, which could expose the active metal or change the $i_{\text {corr }}$ mean values. This method may reveal the value of real and pure corrosion, in which the GC would in fact have values of $i_{\text {corr }}$ higher than the other groups.

There are other studies of corrosion potential in electrolytic environment that show titanium corrosion susceptibility to fluoride $(9,24)$. However, such studies do not take into consideration a factor explored in the present experiment: the difference between immersion every day or every two weeks, which had an influence on the cpTi corrosion type that occurred.

GB and GC (exposed daily to $0.05 \%$ and $0.2 \%$ $\mathrm{NaF}$ solutions, respectively) presented the lowest $i_{\text {corr }}$ mean values. This means that the groups had higher corrosion resistance compared with the other groups (Fig. 3). This resistance can be explained by a more stable film or by the protection of the composites arising from the metal corrosion called deposits, already cited above. Macroscopically, a darkened area, indicated with white arrows in Figure 4 (GB and GC), was observed on the surface of these two groups, representing a real accumulation of composites due to titanium corrosion. These factors may have helped protecting the so-called active metal, which is completely under environmental influence, thereby avoiding major exchanges with the environment and consequently higher levels of corrosion. The lowest mean value found for GC suggested that the greatest accumulation of deposits on the surface of $\mathrm{cpTi}$ was induced by an intense initial corrosion. This causes the required $i_{\text {corr }}$ for the formation of passive film to be lower due to the protective barrier effect of the deposits.

GD and GE (exposed biweekly to $0.05 \%$ and $0.2 \% \mathrm{NaF}$ solutions, respectively) showed higher $i_{\text {corr }}$ value (Fig. 3), meaning that these groups were more affected, as shown by the corrosion tests. This fact implies a weakness of the film formed on the surface of the metal, perhaps due to the difference between daily exposure and exposure every two weeks. It suggests that immersion in the solution of $\mathrm{NaF}$ only once every two weeks causes an insufficient or inefficient recovery of the passivation layer, leaving the surface of the titanium susceptible to the corrosion. Exposing to NaF every 2 weeks was not sufficient to create the deposits on the surface of the material, as this exposure would be fragile in a way that would undermine its reformulation and thus increase the level of corrosion. Furthermore, this high level of corrosion may be due to a layer of corrosion products on the surface of the metal with less protective effects than those formed in GC and GB.

These hypotheses were confirmed by the SEM analysis (Fig. 4), which showed a greater corrosion in the metal exposed daily to the $0.2 \% \mathrm{NaF}$ solution .

In the control GA (Fig. 4), in which the cpTi remained in distilled water, the surface of the specimens was fairly homogeneous with no alterations under SEM. No area was significantly affected by the action of any factor (time or immersion solution), where the samples were immersed for all the 60 days of the experiment. GB (Fig. 4), which was exposed daily to the $0.05 \% \mathrm{NaF}$ solution, showed sparse areas of corrosion in so-called "pits", representing areas where an external agent on the metal surface (indicated by red arrows) has already started acting. In this case, the external agent would be the $\mathrm{NaF}$ solution breaking or damaging the formation of the passive layer, thus making the metal surface susceptible to corrosion. GC (Fig. 4), which was exposed daily to the $0.2 \% \mathrm{NaF}$ solution, was the experimental group most affected by corrosion, as expected. Unlike GA and GB, the areas affected by corrosion were significantly larger and less diffuse, with a concentric shape. Viewing the corrosion at three different magnifications made it easy to see that the degree of corrosion in GC was the one presenting highest intensity and much more punctiform. Thus, the SEM readings suggest that the NaF solution exerts a harmful effect on the cpTi, causing an increased tendency to corrosion. GD (Fig. 4), which was exposed to the $0.05 \% \mathrm{NaF}$ solution every two weeks, had features similar to those found in GB, which was also exposed to $0.05 \% \mathrm{NaF}$ solution. The areas of corrosion in GD were more diffuse and less defined as those in GC (higher concentration). Even having been exposed every 2 weeks, the corrosion pattern of GD is very similar to GB. Group E (Fig. 4), which was exposed to the $0.2 \% \mathrm{NaF}$ solution biweekly, showed areas of corrosion similar to $\mathrm{GC}$, as expected. They were well-marked, delimited and abundant. Furthermore, the areas were well punctiform.

The purpose of this study was to evaluate the effect of fluoride mouthwash solutions on the surface of commercially pure titanium. Based on the results from surface roughness measurements and corrosion 
tests, supported by the SEM analysis, the following conclusion can be inferred: fluoride increased the corrosion tendency in cpTi. Therefore, patients subjected to any intraoral intervention using cpTi (fixed prosthesis, removable dentures, implants or orthodontics) should avoid products with high concentration of $\mathrm{NaF}(0.2 \%)$.

\section{RESUMO}

Os efeitos do fluoreto, o qual está presente em diferentes produtos de higiene oral, necessita de maiores investigações, pois pouco se sabe sobre seus efeitos na superfície do titânio, o qual possui amplo uso na implantodontia. Este estudo objetivou avaliar a superfície do titânio comercialmente puro (cpTi) após exposição a diferentes concentrações de fluoreto de sódio $(\mathrm{NaF})$. A hipótese testada neste estudo foi que diferentes concentrações de $\mathrm{NaF}$ aplicadas em diferentes intervalos de tempo seriam capazes de afetar diferentemente a superfície do titânio. Os tratamentos realizados foram: GA (controle): imersão em água destilada; GB: imersão diária por 3 min em NaF a $0,05 \%$; GC: imersão diária por 3 min em NaF a 0,2\%; GD: imersão quinzenal por 3 min em $\mathrm{NaF}$ a $0,05 \%$; e GE: imersão quinzenal por 3 min em NaF a $0,2 \%$. O tempo do experimento foi de 60 dias. A análise da rugosidade foi efetuada inicialmente e a cada 15 dias. Após 60 dias foi realizada análise de corrosão e polarização anódica. As amostras foram analisadas em MEV. Os dados de rugosidade foram analisados por ANOVA e não houve diferença estatisticamente significante entre grupos e entre tempos. Os dados de corrosão $\left(i_{\text {corr }}\right)$ foram analisados pelo teste de Mann-Whitney e foram encontradas diferenças significantes entre GA e GC, GC e GB, GC e GD, GC e GE. A MEV evidenciou que a superfície do titânio exposto ao $\mathrm{NaF}$ apresentou corrosão variando de acordo com a concentração. Com base nos dados encontrados conclui-se que o uso de solução $\mathrm{NaF}$ a $0,05 \%$ em cpTi é seguro, enquanto a solução $\mathrm{NaF} 0,2 \%$ para uso diário deve ser cuidadosamente avaliada.

\section{REFERENCES}

1. Bergman M. Cast titanium in dental constructions: manuals. Dp Nova Ab. Malmo 1995;26.

2. Di Carlo F, Cassinelli C, Morra M, Ronconi LF, Bassi MA, De Muro G, et al.. Corrosion of titanium in presence of dental amalgams and fluorides. Minerva Stomatol 2003;52:111-121.

3. Hanawa T, Kon M, Ohkawa S, Asaoka K. Diffusion of elements in porcelain into titanium oxide. Dent Mater J 1994;13:164-173.

4. Bijella MFTB, Brighenti FL, Bijella MFB, Buzalaf MAR. Fluoride kinetics in saliva after the use of a fluoride-containing chewing gum. Brazilian Oral Research 2005;19:256-260.

5. Consolaro A, Carvalho RS, Francischone Jr. CE, Consolaro MFMO, Francischone CE. Saucerization of osseointegrated implants and planning of simultaneous orthodontic clinical cases. Dental Press J Orthod 2010;15:19-30.

6. Goodacre CJ, Bernal G, Rungcharassaeng K, Kan JYK. Clinical complications with implants and implant prostheses. J Prosthet Dent 2003;90:121-132.

7. Akça K, Cehreli MC. Biomechanical consequences of progressive marginal bone loss around oral implants: a finite element stress analysis. Med Bio Eng Comput 2006;44:527-535.

8. Toniollo MB, Tiossi R, Macedo AP, Rodrigues RCS, Ribeiro RF, Mattos MGC. Effect of fluoride-containing solutions on the surface of Cast Commercially Pure Titanium. Braz Dent J 2009;20:201204.

9. Schiff N, Grosgogeat B, Lissac M, Dalard F. Influence of fluoride content and $\mathrm{pH}$ on the corrosion resistance of titanium and its alloys. Biomaterials 2002;23:1995-2002.

10. Nakagawa M, Matono Y, Matsuya S, Udoh K, Ishikawa K. The effect of Pt and Pd alloying additions on the corrosion behavior of titanium in fluoride-containing environments. Biomaterials 2005;26:2239-2246.

11. Schiff N, Boinet M, Morgon L, Lissac M, Dalard F, Grosgogeat B. Galvanic corrosion between orthodontic wires and brackets in fluoride mouthwashes. Eur J Orthod 2006;28:298-304.

12. Kaneko K, Yokoyama K, Moriyama K, Asaoka K, Sakai J, Nagumo $\mathrm{M}$. Delayed fracture of beta titanium orthodontic wire in fluoride aqueous solutions. Biomaterials 2003;24:2113-2120.

13. Yokoyama K, Kaneko K, Moriyama K, Asaoka K, Sakai J, Nagumo $\mathrm{M}$. Delayed fracture of Ni-Ti superelastic alloys in acidic and neutral fluoride solutions. J Biomed Mater Res 2004;69:105-113.

14. Huang HH. Variation in surface topography of different NiTi orthodontic archwires in various commercial fluoride-containing environments. Dent Mater 2006;23:24-33.

15. Mabilleau G, Bourdon S, Joly-Guillou ML, Filmon R, Basle MF, Chappard D. Influence of fluoride, hydrogen peroxide and lactic acid on the corrosion resistance of commercially pure titanium. Acta Biomater 2006;2:121-129.

16. Stajer A, Radnai M, Pelsoczi KI, Turzo K, Oszko A, Fazekas A. The effect of fluorides on the surface structure of titanium implants. Fogorv Sz 2006;99:53-59.

17. Galo R, Ribeiro RF, Rodrigues RCS, Rocha LA, Mattos MGC. Effects of chemical composition on the corrosion of dental alloys. Braz Dent J 2012;23:141-148.

18. Hruska AR, Borelli P. Quality criteria for pure titanium casting, laboratory soldering, intraoral welding, and a device to aid in marking uncontaminated castings. J Prosthet Dent 1991;66:561565.

19. Elagli K, Traisnel M, Hildebrand HF. Electrochemical behaviour of titanium and dental alloys in artificial saliva. Pergamon Press Ltd 1993;38:1769-1774.

20. Geis-Gerstofer J. In vitro corrosion measurements of dental alloys. J Dent Res 1994;22:247-251.

21. Landolt D, Mischeler S, Stemp M, Barril S. Third body effects and material fluxes in tribocorrosion systems involving a sliding contact. Wear 2004;256:517-524.

22. Ponthiaux P, Wenger F, Drees D, Celis JP. Electrochemical techniques for studying tribocorrosion processes. Wear 2004;256:459-468.

23. Berradia A, Bratu F, Benea L, Willems G, Celis JP. Effect of sliding wear on tribocorrosion behaviour of stainless steels in a Ringer's solution. Wear 2006;261:987-993.

24. Toumelin-Chemia F, Rouellet F, Burdairon G. Corrosive properties of fluoride-containing odontologic gels against titanium. J Dent 1996;24:109-115.

Received June 2, 2011 Accepted August 14, 2012 